\title{
Revamping the design of Preschoolers Islamic Education by Integrating Islamic Design Principles and Cognitive Theory of Multimedia Learning: A Needs Assessment Study
}

\author{
Wan Irma Sabrina Idrisa*, Rafiza Abdul Razaka, Siti Hajar Halilia ,Siti Soraya Abdul Rahman ${ }^{\mathrm{b}}$, Hasleena Hamzah \\ ${ }^{a}$ Faculty of Education, University of Malaya, Petaling Jaya, Kuala Lumpur \\ ${ }^{b}$ Faculty of Information Technology, University of Malaya, Petaling Jaya, Kuala Lumpur \\ 'Faculty of Leadership and Management, Islamic Science University of Malaysia, Nilai, Negeri Sembilan \\ *Corresponding author: sabrina@utar.edu.my
}

Article history: Received 20 November 2017 Received in revised form: 13 March 2019 Accepted: 07 May 2019 Published online: 31 August 2019

\begin{abstract}
This study aims at identifying the needs in applying Islamic Design Principles in developing multimedia learning for Islamic Education among children. Teaching methods of Islamic education have not seen much improvement and lack of creativity. Current designs and content of multimedia learning materials were not suitable in teaching Islamic education. Thus this study initiated in integrating Islamic design principles; 1) Tawheed, 2) Dhikir 3) Haya and 4) Iqtisad with Cognitive Multimedia Learning Theory. It involved a needs analysis survey research design concerning parents and teachers of preschool as participants. The result of this study indicated positive responses received upon this matter indicating that the elements of Islamic design principles were relevant in multimedia learning for preschool Islamic Education. The integration of multimedia learning theory and Islamic Design Principles in designing multimedia learning for children. This was because the impacts of multimedia learning and Islamic design principles were important for the future of early children education, it was sensible for Islamic design principles were applied to multimedia learning content. There was a need to develop learning aids in teaching Islamic values education to the children. Multimedia learning can help in sculpting the Islamic character of the children while coaching them the virtuous values in Islam; an example of the ethic in Prophet Muhammad (P.B.U.H.), good behavior and action will help the children in their personal life. Besides, this paper will help instructional design to design and develop a multimedia learning for Islamic preschool in future.
\end{abstract}

Keywords: Islamic design Principles, Multimedia learning theory, preschoolers, instructional technique.

Abstrak

Kajian ini bertujuan untuk mengenal pasti keperluan menerapkan Prinsip Rekabentuk Islam dalam membangunkan pembelajaran multimedia bagi Pendidikan Islam di kalangan kanak-kanak. Kaedah mengajar pendidikan Islam tidak banyak memperlihatkan peningkatan dan kurang daya kreativiti. Reka bentuk semasa dan kandungan bahan pembelajaran multimedia tidak sesuai untuk mengajar pendidikan Islam. Oleh itu, kajian ini dimulakan dalam mengintegrasikan prinsipprinsip reka bentuk Islam; 1) Tawheed, 2) Dhikir 3) Haya dan 4) Iqtisad dalam Teori Pembelajaran Multimedia Kognitif. Ia melibatkan reka bentuk kajian keperluan kaji selidik yang melibatkan ibu bapa dan guru prasekolah sebagai peserta. Hasil kajian menunjukkan tanggapan positif yang diterima atas perkara ini yang menunjukkan bahawa unsur-unsur prinsip reka bentuk Islam adalah relevan dalam pembelajaran multimedia untuk Pendidikan Islam prasekolah. Penyepaduan teori pembelajaran multimedia dan Prinsip Rekaan Islam dalam merancang pembelajaran multimedia untuk kanak-kanak. Ini kerana kesan pembelajaran multimedia dan prinsip reka bentuk Islam adalah penting untuk masa depan pendidikan kanak-kanak awal. Makai ia adalah wajar untuk prinsip reka bentuk Islam digunakan untuk kandungan pembelajaran multimedia. Terdapat keperluan untuk membangunkan alat bantu mengajar dalam mengajar pendidikan nilai Islam kepada kanak-kanak. Pembelajaran multimedia dapat membantu memupuk watak Islam kanak-kanak sambil melatih mereka nilai-nilai mulia dalam Islam; contoh etika Nabi Muhammad S.A.W, tingkah laku dan tindakan yang baik akan membantu kanak-kanak dalam kehidupan peribadi mereka. Selain itu, kertas kerja ini akan membantu reka bentuk pengajaran untuk merekabentuk dan membangunkan pembelajaran multimedia untuk prasekolah Islam pada masa akan datang.

Kata kunci: Prinsip reka bentuk Islam; teori pembelajaran multimedia; kanak-kanak prasekolah; teknik pengajaran

(C) 2019 Penerbit UTM Press. All rights reserved

\subsection{INTRODUCTION}

Emerging technology and education over the past decade have dramatically changes the social and communication activities (Filigree, 2012). Regardless of age and cultural background, internet and mobile network have played important role in everyone's life (Murray and Perez, 2011; Talacon and Lieu, 2012; Greenfield, 2013). In education for instance, the use of these technologies is expanding especially in positions of having the learning process in 'anytime' and 'anywhere'. Nowadays, education was no longer necessary to be in a classroom as in the 
traditional method. Dani and Vanishree (2013) quote, flexible inventions for communication and knowledge transfer were progressively change the way people lived; this enable them to receive data whenever and wherever they want.

Nonetheless, online learning and multimedia learning was widely used in schools, universities and home-education either as an aid of primary resources or as the main education itself. The same scenario can be seen in early childhood education. Study done by Penuel et al's (2012) who experimented the effects of multimedia learning in preschool where the result showed children who received media aid produce better improvements on the acknowledgement, story concept and phonics. "Currently, multimedia learning have been frequently used to cater the early learning purpose; this was due to their influence and targeting to the young public" (Presky, 2011). These children grew in a new era, in which there's an extensive of varied range of latest technologies were employed either at school or home. Moreover, the National Association for the Education of Young Children (NAEYC, 2012) have given full supports on the development of appropriate and intentional use of technology in early childhood education. Thus, to ignore the significance would cause a reproductive curriculum which risks of being out of step with children's actual lives.

However, the issue of multimedia learning materials were rarely used positively has received considerable critical attention. "Most of multimedia learning materials were invented for entertainment and commercial used rather than transferring knowledge and information" (Gee, 2003). In addition, current designs and content of multimedia learning materials were not suitable in teaching Islamic education. This was due to the influenced of western design principles in the design and content of multimedia learning. According to Grabar (2006), the western artistic taste has somewhat dictated and influenced the attitude of Muslims and Non-Muslims to the extent that they become prejudiced toward Islamic art and design. Burckhardt (2009) added that due to the domination of western art in the global scene, Islamic art remained a neglected field of study among art researcher. "Though the Prophetic model of Islamic education and design were implementing the appreciation towards Allah creation, it was undoubtedly draw much of its content from the foundation disciplines of Islamic studies (Aqidah, Tafseer, Fiqh, Sirah, etc), and Islamic Principles of design (Dhikir, Tawheed, Haya, Iqtisad)" (Haron, 2014). Determining the impacts of multimedia learning and Islamic design principles were important for the future of early children education, it was sensible for Islamic design principles were applied to multimedia learning content. In addition, due to the aspects highlighted, multimedia learning can also play an effective role in building the Islamic personality of the children while teaching them the good values in Islam; an example of the ethic in Prophet Muhammad (P.B.U.H.), good behavior and action will help the children in their personal life.

Hence to the above issues, this paper was reporting the needs analysis from the survey conducted on parents and preschool teachers' base on the needs of integration multimedia learning theory and Islamic Design Principles in designing multimedia learning for children.

\section{Problem Statement}

The vast influence of the western and secular materialism on current multimedia learning content has challenge parents and teachers in finding appropriate learning aids in teaching Islamic values education to the children. Tauhidi (2001) stated, the wisdom of restoration was in the air today where educated Muslims were excited to find real resolutions to the glitches and challenges faced by the Muslim community and if essential to re-examine traditional paradigms within Muslim society-including what and how they educate their children about Islam.

However, Islamic scholars highlighted that the methods of memorization, imitation and lack of creativity have dominated Islamic pedagogy for centuries. Rahman (2004) wrote that being based on memorization of medieval texts, resulted the Islamic school were not providing relevant education to the Muslim society. In addition to this issue, leads to the age of stagnation; where teaching methods and in Islamic education institutions have not seen improvement. Concerned on teacher's preparation and readiness towards technology changes has been identified in several studies. "Most teachers were the products of madrasah system itself and have no or minimal exposure to the alternative ways of teaching or encouraging their students to ask questions about what they were being taught" (Abdalla, Abu Nimar, Nasser, Kadayific, Kunkle, and Kilani, 2003). Recent studies also outlined that the needs of technology and innovation should be implement in providing better education to the young generation. Rahman (2004) explained, in order to empower the Islamic community, there is no harm in borrowing technology and other concepts from the West. Though these statement might be argued but there is nothing essentially wrong with these views since they do promote modernity but not at the cost of losing one's religious and cultural identity.

None the less, in a book entitled: Ta'lim al-Muta'allim-Tariq at-Ta'-allum (Instruction of the Student: The Method of Learning), written by Imam Zarnuji, a thirteenth century scholar outlined numbers of foundational characteristic of Islamic pedagogy which emphasis on (1) the nobility of learning; (2) the importance of intention when learning; (3) the assiduity with which learning should be approached; and (4) the purpose of learning being to put knowledge into action and to control one's lower self through the very act of learning (Zarnuji, 2011).

Although extensive research has been carried out on the innovation of multimedia learning, none of the study cover the area of implementing Islamic design principles into multimedia learning material. Undoubtedly, all the issues highlighted summarized the needs of integrating technology and innovation in multimedia learning onto the Islamic education along with the Islamic design principles.

\subsection{LITERATURE REVIEW}

\section{The Importance of Islamic Education For Young Children}

Education is a fundamental right. Each person, despite from any age, financial background which country or race you are from, or culture is entitle to it. In Islam, education is very important as Muslims are positively encouraged the value of collecting information and distribute to all people as in sharing the knowledge to the world. The Islamic education's vision and objectives were conserved in the history through the communication between past (tradition) and innovation (modernity). The tradition helps to develop a stable identity while the modernity help to develop flexibility. The indelibility of the knowledge acquired by young and innocent children suggests the paramount importance of early childhood education. Knowledge in childhood is likened to an engraved mark on a rock, which is difficult to rub off. As it is better to train boys than to mend men, the Holy Prophet Muhammad (P.B.U.H.) emphatically mentioned it that children must be religiously educated in their early stages. According to Ahmad, Ahmad, Saufi, Dziaudin, Nilofar and Siti (2006), in Islamic perspective, education is a 
process of conveying knowledge or moral values that help in developing the whole potential of human nature, emotionally and physically producing compact and sensible individuals who will be able to perform human responsibility as Allah's caliph on the earth

Subsequently, with the advancement of ICT, parents, guardian and Muslim educators, need to prepare themselves with ICT skills especially multimedia in order to furnish the growth of students in all aspects; intellectual, imaginative, spiritual, linguistic, physical and scientific collectively. Muslim who believes in Allah's power; the human achievement in ICT enable another platform of knowledge achievement where it can be used in order to find a truth as Allah says in the Quran: "We shall show them our signs in the horizons, and in their own souls, until it becomes clear to them that it, namely, the Qur'an is the truth, is it not sufficient that your Lord is witness to all things."[41:53]. Thus, as educator, researcher, parents and teachers, it is our duty to comply our young children with the appropriate education, guided by our religion. The worst if the role of knowledge disseminator, value cultivator and skill enhancer will no longer be significant, since the students will be able to scout everything they need outside classrooms but without a appropriate supervision.

Therefore, in order to fulfil the need and cater to these young children; digital natives, this paper will focus on adapting Islamic content into the multimedia learning.

\section{Islamic Design Principles}

The adaptation of Islamic Principles in art and design was not a new approached; it started with the design on buildings, architecture and calligraphy but later developed onto the art and aesthetics design. Artists drew lessons and methods from their experienced of the Qur'an, developing a new approach to art characterised by the independence and interdependence of its formative elements. The emphasis was on the presence and attributes of the divine Creator. This demonstrated the amazing achievement of Islamic civilization and how Islam values and appreciate art and design. Umar (2013) stated; beauty in Islamic perspective was not just for the sake of visual pleasure but comes with a purpose. He also added that the purpose was to make humans submit to Allah's divinity; by acknowledging and remembering Allah through His creation, humans will find the true meaning of beauty. According to the Quran: "It is He who created for you all of that which was on the earth. Then He directed Himself to the heaven, [His being above all creation], and made them seven heavens, and He is Knowing of all things." [1:29]. Ali (2007) in her written; Beauty and Aesthetic in Islam mentioned that the existence of the highest form of knowledge is cultivated through the relationship between reason and intellect. She also claimed that only in Islamic Art, a Muslim can acquired this 'knowledge' either by "creating it or by contemplating its beauty". Thus, this showed the significant of us as Muslim to value and adapt Islamic Art in any field that we do; in remembrance of Allah and His creation.

Several debates by scholars on the existence of Islamic Principles in design. Merely, most art and design school design their syllabus and curriculum based on western art education or western visual perception theory such as Gestalt Principles (Khan, 2003). Gestalt means "unified whole" in psychology terms referred to theories of visual perception developed by German psychologist in the 1920s. These theories described the method of organizing visual elements into groups when certain principles were used. The principles were; similarity, continuation, closure, proximity and figure and ground. Since this principles have been well used in our art field, the relationship between art and Islam has always been a stimulating debate among Islamic scholars.

Grabar (2006) argued that the western artistic taste has dictated and influenced Muslim's artist and made them become prejudiced toward Islamic art. In supporting this issue, Burckhardt (2009) also claimed that Islamic art has remained a neglected field of paper among art researchers due to the domination of western art in global scene. In addition, Tarmizi and Said (2009) stated, the young generation artists in Malaysia nowadays were becoming more westernized and that they began to see art as a medium of self-expression rather than the worship towards the beauty of Allah's creation. None the less, this way of thinking was likely to affect the traditional art in Malaysia. Hence, it was important for researcher to adapt Islamic Principles in the design and development of this paper in order to fulfil the duty of Muslim scholar.

Based on research done by Harun (2014), there were four Islamic Principles that were best to represent visual perception in art and design. There were; Tawheed, Iqtisad, Haya and Dhikir (refer table 1 for further definition).

Table 1 The Islamic Principles and meaning.

\begin{tabular}{lll}
\hline Islamic Principles & Primary Meaning & Secondary Meaning \\
\hline Tawheed & Oneness & Unity and harmony \\
Iqtisad & State of being even & Balance \\
Haya & Modesty, moderate & Simplicity \\
Dhikir & Remembrance of Allah & Memorable and affection \\
\hline
\end{tabular}

The adaptation of these four Islamic Principles in the design and development of multimedia learning were relevant base upon its function in disseminate Islamic knowledge towards young Muslim children.

\section{Multimedia Learning Theory- Cognitive Theory of Multimedia Learning}

Cognitive theory of multimedia learning by Mayer's $(2001 ; 2009)$ experiments were focused on the auditory/verbal channel and the visual channel. Mayer defined multimedia as the presentation of material using both words and pictures. Thus, the definition of multimedia was narrowed down to two forms of information: verbal and pictorial or visual. This was because the research based in cognitive psychology was most relevant to this definition. Consequently, this model was based on three primary assumptions highlighted by Mayer (2009); (1) visual and auditory experiences or information were processed through separate and distinct information processing 'channels'; (2) each information processing channel was limited in its ability to process experiences or information and (3) processing experiences or information in the channels form an active process designed to construct coherent mental representations.

On the other hand, this paper was also looking at Mayer's Design Principles (2001) and other several scholars' research paper prior to find the needs of integrating Islamic Design Principles and Multimedia Learning Theory in designing multimedia learning content for preschooler. According to Mayer (2001), an effective learning can be achieved by the interaction during the learning process based on the seven 
principles; (1) Multimedia Principle; "Students learnt better from words and pictures than from words alone". Mayer and Moreno (2003) in another similar study stated that, the theoretical rationale for multimedia principle was that the students were able to corresponding better to words and pictures when both were presented together. (2) Spatial Contiguity Principle; "Students learnt better when corresponding words and pictures were presented near rather than far from each other on the page or screen". This principle however was supported by other similar study on the recognition memory by Schwarts, Howard, Jing and Kahana (2005) where the effects of recognition memory shows "adjacent items were recognized significantly better than remote items". (3) Temporal Contiguity Principle; "Students learnt better when corresponding words and pictures were presented simultaneously rather than successively". Mayer and Moreno (2003) explained, the rationale of temporal contiguity principle was that "learners were better in making mental connection in working memory when corresponding with words and pictures presented at the same time". (4) Coherence Principle; "Students learnt better when extraneous words, pictures, and sounds were excluded rather than included". Reporting on an analysis of Coherence Principle in Multimedia Design, Thayer, M. (2011) mentioned that, Coherence Principle was a principle of how people learn; while the cognitive theory of multimedia learning outline that people have certain limitation in receiving information on their working memory, unnecessary audio and graphic can overload learner's working memory and obstruct learning process.

However, there were an argument suggesting that some extraneous content can be an advantages in multimedia learning since it may arouses learner's interest. In response, Clark and Mayer (2008) claimed that an entertaining but irrelevant content may only distracted learner rather than making the learning more interesting. Consequently, Clark and Mayer (2008) were also stressed out on the lack of research in some areas where previous research has shown that learners learn better if they are interested in the content presented, but a level of 'balance' must be found that promotes learner interest without causing undue distraction. (5) Modality Principle; Students learnt better from animation and narration than from animation and on-screen text. Several scholars have similarly demonstrated this principle. Ginns (2005) provided significant support through his study; reporting a medium to large effect on this principle. None the less, regardless the strong evidence were in favour of modality effects, Ginns (2005) claimed that most of the studies have been limited to educational domains rather than higher order cognitive skills, such as decision-making. Significant to this issue, O'Neil et al. (2010) conducted a study within his matter and the results indicated that participants receiving narrated feedback performed better than those receiving printed-text feedback in transferring, matching and knowledge mapping test. (6) Redundancy Principle; Students learnt better from animation and narration than from animation, narration and on-screen text. Supporting this principle, Kalyuga, Chandler, \& Sweller, (2004) stated that, students learnt better from multimedia messages when it were consisted of narration and visual displays rather than when it were consisted of narration, onscreen text and visual displays. According to this study, extraneous processing of two redundant input causes the redundancy effect. These resulted in the disruption of beneficial cognitive processes associated with effectiveness of organizing the multimedia message in working memory and integrating relevant knowledge. (7) Individual Differences Principle or Personalization Principle; Design effects were stronger for low-knowledge learners than for high-knowledge learners and for high-spatial learners rather than for low-spatial learners. In five out of five experimental studies done by Mayer and Moreno (2003) shown students performed better on transfer tests when words were presented in conversational rather than formal style. Table 2 illustrated summary of the seven principles of multimedia learning.

Table 2 Summary of seven principles of multimedia learning

\begin{tabular}{ll}
\hline Design Principles & Descriptions \\
\hline Multimedia Principle & The student were able to corresponding better to words and pictures when both are presented together. \\
\hline Spatial Contiguity Principle & $\begin{array}{l}\text { The effects of recognition memory shows "adjacent items were recognized significantly better than remote } \\
\text { items }\end{array}$ \\
\hline Temporal Contiguity Principle & $\begin{array}{l}\text { Learners were better in making mental connection in working memory when corresponding with words } \\
\text { and pictures presented at the same time }\end{array}$ \\
\hline Coherence Principle & $\begin{array}{l}\text { People have certain limitation in receiving information on their working memory, unnecessary audio and } \\
\text { graphic can overload learner's working memory and obstruct learning process. }\end{array}$ \\
\hline Modality Principle & Students learnt better from animation and narration than from animation and on-screen text. \\
\hline Redundancy Principle & $\begin{array}{l}\text { Students learnt better from multimedia messages when it were consist of narration and visual displays } \\
\text { rather than when it were consist of narration, on-screen text and visual displays. }\end{array}$ \\
\hline $\begin{array}{l}\text { Individual Differences } \\
\text { Personalization Principle }\end{array}$ & Principle \\
\hline
\end{tabular}

This proved that the rationale for personalization principle clarified that students work harder to understand an explanation when they were personally involved in the conversation. It was strongly believed that all seven principles were relevant and should be included in the research content.

\subsection{CONCEPTUAL FRAMEWORK}

In order to analyse the needs of integrating multimedia learning into Islamic design principles, blended theories of Islamic design principles (Harun, A., 2014) and cognitive multimedia learning theory by Mayer (2001) will be implemented. (Refer figure 1). 


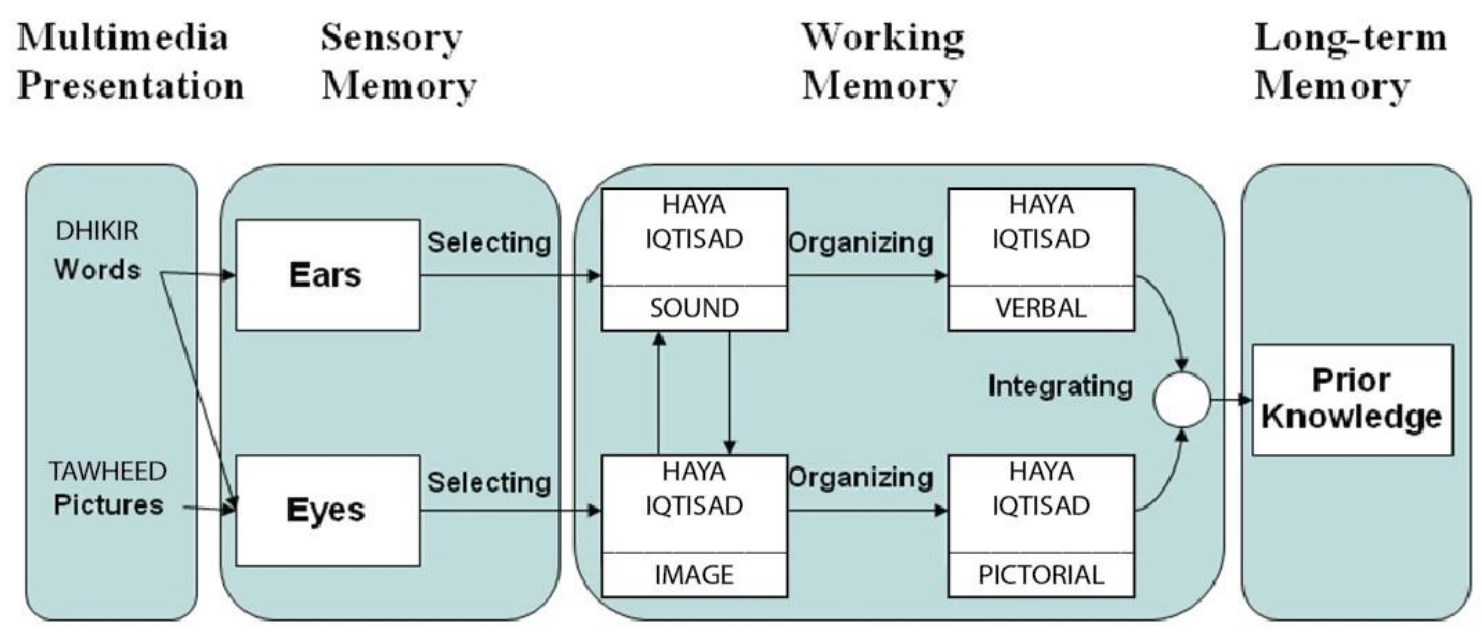

Figure 1 The implementation of islamic design principles onto cognitive multimedia learning theory.

Referring to the above figure, conceptual framework was developed by integrating the Islamic Design Principles (Harun, A., 2014) onto Cognitive Multimedia Learning Theory (Mayer, 2001). These two theories were chosen as both have the concept of design elements that were relevant and relatable. Consequently, the four elements in Islamic design principles; (1) Tawheed means 'Oneness' or unity and harmony, (2) Iqtisad means 'state of being even' or balance, (3) Haya as in 'modesty', 'moderate' or simplicity and (4) Dhikir which giving the meaning of 'remembrance of Allah' or memorable and affection were implement in cognitive multimedia learning theory base on the meaning and suitability of each principle and theory.

Cognitive Multimedia Learning Theory by Mayer (2001) or Cognitive Load Theory explained the human memory process, where there were four (4) stages and the process starts with multimedia presentation. Multimedia presentation was defined as a presentation consisting of words and pictures that was designed to foster meaningful learning. Thus there were two parts to the definition; the presentation contains words and pictures and the presentation was designed to foster meaningful learning (Mayer, 2003). Since the meaning of 'Dhikir' was memorable and 'Tawheed' as unity/harmony, these two elements were suitable to be implement in the text/ words and images/ pictures in presenting content of multimedia learning. While multimedia learning content were presented to the audience or children, sensory memory will received the information through five senses. As a receiver; sensory memory was the shortest information after the original stimuli have ended. It acts as kind of buffer for stimuli received through the five senses of sight, hearing, smell, taste and touch, which were retained accurately (Lu, Z. L. \& Sperling G., 2003). This was where ears and eyes will selecting and grasping information. Subsequent, information from sensory memory will be transmitted to working memory. Working memory is also known as "mind stores information for short periods of time prior to acting on it or integrating it with other information", (Flaskerud, 2013) which will be process, organise and integrate the information. Based on empirical study reported by Leahy \& Sweller (2011), Cognitive Load Theory claimed that working memory was limited in 'capacity' and 'duration'; complicated information may be considered to have negative load consequences on young learners' working memory. Thus, considering this aspect 'Haya' which means moderate and 'Iqtisad' means balance were implemented in working memory stages where information from sensory memory transmitted into sound, images or visuals in working memory that were organized and integrated.

Finally, information gathered will be transform into knowledge and will be stored in long term memory. Long-term memory was intended for storage of information over a long period of time that will store information in schemas, where mental structures used to organize and structure knowledge. It had been thought that once it happened, it makes a profound impression on long-term memory (Flaskerud, 2013).

\subsection{METHODOLOGY}

\section{Research Approach}

Analysis Assessment was conducted among teachers and parents as to get information on the needs of multimedia learning usage in teaching preschools children. None the less, the assessment was also looking into the implementation of Islamic design Principles onto cognitive multimedia learning theories. Information gathered on the issues and as well as new-insight highlighted solutions for future design and the development of multimedia learning. Design research has an interventionist nature that aims to solve problems in educational practice by designing innovative interventions and enacting and refining theories and design principles (Wang \& Hannafin, 2005). Eventually, the process begins with problem definition arrived at in concert with practitioners and integrated with in-depth investigation and analysis of the current literature to enact conjectured initial theories. 


\section{Data Collection Technique}

Data were collected to analyse a survey on the acceptance and perception of parents and teachers towards the implementation of multimedia application in Islamic pre-school learning. In order to gather all the data in this phase, need analysis assessment was conducted towards parents and teachers.

\section{Data Analysis Technique}

Questionnaires constructed base on the design and needs of Islamic multimedia design apps. There were two (2) parts of analysis where first part concentrated on the implementation of Islamic Design Principles and the second part was on the usage of multimedia learning in school. Analysis questionnaire was developed base on the frequency scale as $1=$ strongly disagree, $2=$ Disagree, $3=$ Unsure, $4=$ Agree and $5=$ strongly agree. These questions were constructed as to understand the application of Islamic Principles of design and the elements of Multimedia Learning in current Multimedia apps design for children's digital multimedia learning.

\section{Participant of the Study}

Fifty parents and twenty teachers from Islamic pre-school children aged six years old from Shah Alam district were chosen in gathering data for this stage. There were four different Islamic pre-school all around Shah Alam area were selected. Schools were selected based on their similar approach on education method as Islamic Kindergarten. Respondents were chosen based on purposive sampling and demographic area due to the limitation of this research.

\subsection{RESULTS AND DISCUSSION}

Data gathered from survey were analysed base on the percentage of respondents' selection frequency. Subsequently, these data were divided into two parts where the first survey was looked into the implementation of Islamic design principles in multimedia learning and the second part of the survey was focused on the importance of multimedia learning in preschool education (refer table 3 and 4 for the detail of data collected during the survey).

Table 3 Participants responses towards the needs of Islamic design Principles in designing multimedia learning

\begin{tabular}{llllll}
\hline & $\begin{array}{l}\text { Strongly } \\
\text { disagree }\end{array}$ & Disagree & Unsure & Agree & Strongly Agree \\
\hline $\begin{array}{l}\text { Unity: Pre-schooler able to learn the } \\
\text { social skills, play and work with other } \\
\text { children. }\end{array}$ & $3.2 \%(2)$ & $3.2 \%(2)$ & $19 \%(12)$ & $57.1 \%(36)$ & $17.5 \%(11)$ \\
$\begin{array}{l}\text { Balance: Pre-schooler have a safe, } \\
\text { structured environment for them to } \\
\text { explore and face new challenges. }\end{array}$ & & $3.2 \%(2)$ & $19 \%(12)$ & $54 \%(34)$ & $20.6 \%(13)$ \\
$\begin{array}{l}\text { Simplicity: Pre-schooler display } \\
\text { initiative, curiosity, the desire to explore, } \\
\text { and enjoyment without feeling guilty or } \\
\text { inhibited. }\end{array}$ & & $3.2 \%(2)$ & $15.9 \%(10)$ & $54 \%(36)$ & $20.6 \%(13)$ \\
$\begin{array}{l}\text { Memorable: Pre-schooler learn through } \\
\text { 'watch' and 'tell/listen'. }\end{array}$ & $4.8 \%(3)$ & $0 \%(0)$ & $19.4 \%(12)$ & $43.5 \%(27)$ & $32.3 \%(20)$ \\
\hline
\end{tabular}

Referring to table 3, on the needs of Islamic design Principles in designing multimedia learning, reporting on the highest percentage of frequency using Likert scale model; (1) strongly disagree, (2) disagree, (3) unsure, (4) agree and (5) strongly agree.

Looking at 57.1 percent (36) parents and teachers responded that they are agree that the principles of 'unity' in Islamic design principles will enable the pre-schooler to learn the social skills, play and work with other children; 54 percent (34) select to agree on the principle of 'balance' will ensure the pre-schooler have a safe, structured environment for the children to explore and face new challenges; while 54 percent (36) select to agree on the principle of 'simplicity' will motivate pre-schooler initiative, curiosity, the desire to explore, and enjoyment without feeling guilty or inhibited and 43.5 percent (27) are agree on the principle of 'memorable' will guide the pre-schooler to be a better person as they learn through 'watch' and 'tell/listen'. 
Table 4 Participants responses towards the needs of Multimedia Learning in preschool children's education.

\begin{tabular}{|c|c|c|c|c|c|}
\hline & $\begin{array}{l}\text { Strongly } \\
\text { disagree }\end{array}$ & Disagree & Unsure & Agree & Strongly Agree \\
\hline $\begin{array}{l}\text { Pre-schooler learn better from words and } \\
\text { pictures than from words alone. }\end{array}$ & $1.6 \%(1)$ & $4.8 \%(3)$ & $12.7 \%(8)$ & $49.2 \%(31)$ & $31.7 \%(20)$ \\
\hline $\begin{array}{l}\text { Pre-schooler learn better when } \\
\text { corresponding words and pictures are } \\
\text { presented near rather than far from each } \\
\text { other on the page or screen. }\end{array}$ & $1.6 \%(1)$ & $0 \%(0)$ & $17.5 \%(11)$ & $50.8 \%(32)$ & $30.2 \%(19)$ \\
\hline $\begin{array}{l}\text { Pre-schooler learn better when } \\
\text { corresponding words and pictures are } \\
\text { presented simultaneously rather than } \\
\text { successively. }\end{array}$ & $1.6 \%(1)$ & $3.2 \%(2)$ & $23.8 \%(15)$ & $54 \%(34)$ & $17.5 \%(11)$ \\
\hline $\begin{array}{l}\text { Pre-schooler learn better when extraneous } \\
\text { words, pictures, and sounds are excluded } \\
\text { rather than included. }\end{array}$ & $15.9 \%(10)$ & $25.4 \%(16)$ & $20.6 \%(13)$ & $30.2 \%(19)$ & $7.9 \%(5)$ \\
\hline $\begin{array}{l}\text { Pre-schooler learn better from animation } \\
\text { and narration than from animation and on- } \\
\text { screen text. }\end{array}$ & $1.6 \%(1)$ & $9.5 \%(6)$ & $27 \%(17)$ & $49.2 \%(31)$ & $12.7 \%(8)$ \\
\hline $\begin{array}{l}\text { Pre-schooler learn better from animation } \\
\text { and narration than from animation, narration } \\
\text { and on-screen text. }\end{array}$ & $3.2 \%(2)$ & $15.9 \%(10)$ & $30.2 \%(19)$ & $41.3 \%(26)$ & $9.5 \%(6)$ \\
\hline $\begin{array}{l}\text { Design effects are stronger for low- } \\
\text { knowledge learners than for high- } \\
\text { knowledge learners and for high-spatial } \\
\text { learners rather than for low-spatial learners. }\end{array}$ & $3.2 \%(2)$ & $4.8 \%(3)$ & $47.6 \%(30)$ & $36.5 \%(23)$ & $7.9 \%(5)$ \\
\hline
\end{tabular}

Table 4 displays participants responses towards the needs of multimedia learning in preschool children's education; reporting on the highest percentage of frequency from Likert scale model; (1) strongly disagree, (2) disagree, (3) unsure, (4) agree and (5) strongly agree.

It can be seen from the data in table 2 that, $49.2 \%$ (31) of respondents agree on the statement of pre-schooler learn better from words and pictures than from words alone. There are large percentage of $50.8 \%$ (32) of respondents choose to agree on the statement of pre-schooler learn better when corresponding words and pictures are presented near rather than far from each other on the page or screen and 54\% (34) are agree on pre-schooler learn better when corresponding words and pictures are presented simultaneously rather than successively. Subsequently, 30.2\% (19) agree on pre-schooler learn better when extraneous words, pictures, and sounds are excluded rather than included; $49.2 \%$ (31) agree on pre-schooler learn better from animation and narration than from animation and on-screen text. Finally, looking at another positive response on $41.3 \%$ (26) for pre-schooler learn better from animation and narration than from animation, narration and onscreen text. However, on the last statement of the survey, highest response from respondents selected 'unsure' for design effects are stronger for low-knowledge learners than for high-knowledge learners and for high-spatial learners rather than for low-spatial learners on percentage of $47.6 \%(30)$.

\section{Research Implication}

An initial aims of the research paper was to determine the needs of applying Islamic Design Principles in developing multimedia learning for Islamic Education among preschool children. Thus from the findings, indicated positive responses received upon this matter indicating that the elements of Islamic design principles are relevant in multimedia learning for preschool Islamic Education (Prince, M., 2004). Prior to this, it could been said that, the result have shown an innovation of Islamic design principles where; this study had underlined the needs for Islamic instructional design strategy to design and develop a multimedia learning for preschool Islamic Education for the future. Subsequently, it is significant of this research to adapt the conceptual research framework into an inventive of Islamic multimedia learning framework in the instructional design strategy for the development of the multimedia learning for preschooler (Walsh, K., 2010).

Refer figure 2 .

\section{Discussion}

Prior studies that have noted the importance of technology and innovation in education. This paper set out with the aim of analysing the needs of integrating multimedia learning theory and Islamic Design Principles in designing multimedia learning for children. The result of this study indicate positive responses received upon this matter. Surprisingly, most of the respondents choose to 'agree' to all principles in Islamic design are important in designing multimedia learning. None the less, the result also shows that respondents rank 'unity' as the most important followed by 'balance' and 'simplicity' and lastly 'moderate' (refer Figure 2). 


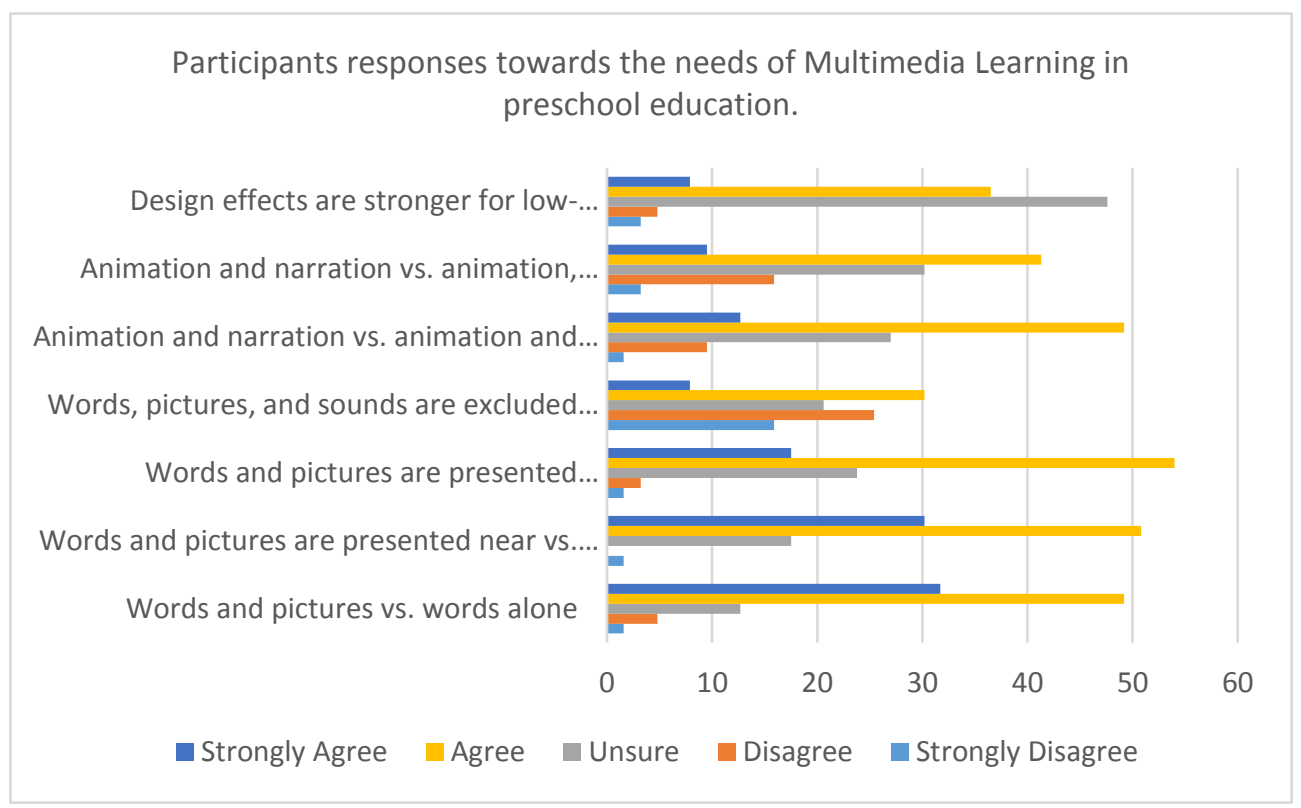

Figure 2 Participants responses towards the needs of Islamic design Principles in designing multimedia learning

This rather surprising finding could be due to the elements in Islamic design principles are relevant in teaching and learning for preschool education. Meanwhile looking at Figure 3, almost all of the responses are positive. Virtually of the highest items on the needs of multimedia learning in preschool children's education rank 'agree' accept for the last item where 'design effects are stronger for low-knowledge learners rather than high-knowledge learners and for high-spatial learners' which the highest rank indicate 'unsure'. Successively, Figure 3 also presented that the highest item that should be implement in multimedia learning is 'words and pictures are to be presented simultaneously' .As quoted by Mayer and Moreno (2003), learners are better in making mental connection in working memory when corresponding with words and pictures presented at the same time. This rank was later followed by 'words and pictures are to be presented near each other on screen' and respondents also prefer 'animation and narration rather than on screen text' (refer Figure 3).

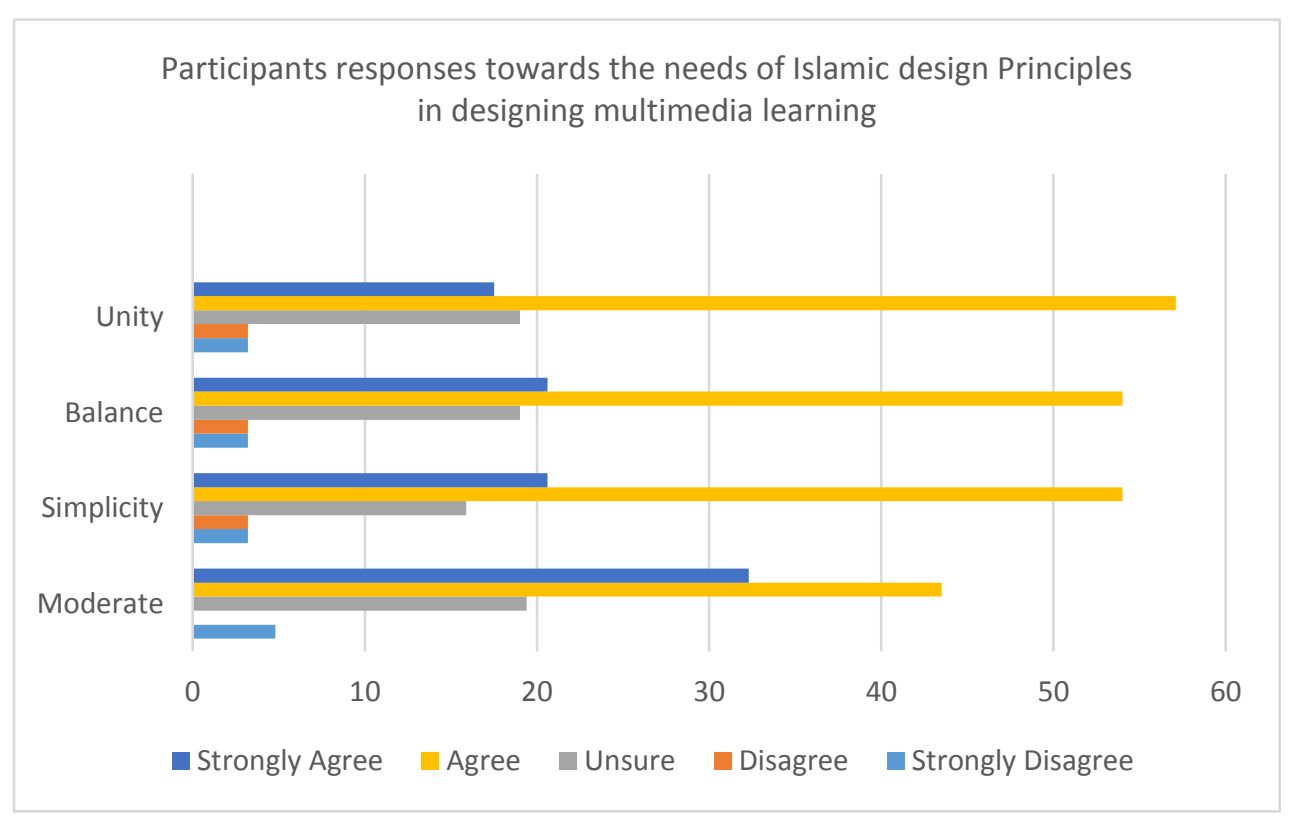

Figure 3 Participants responses towards the needs of Multimedia Learning in preschool education.

Very little was found in the literature on the matter of implementing Islamic design principles in preschool education, but a strong relationship between integrating technology and teaching religion has been reported in the literature. The adaptation of ICT in education has led to shift from traditional methods of teaching religion subjects from face-to-face classroom environment onto an environment where technology has become significant component to deliver overall learning infrastructure (Jone and Sims, 2002). 
Hedge and Haward (2004) stated that a good innovative well-designed multimedia learning approach in delivering electronically mediated, learner-centred an interactive learning environment to anyone, anytime and anyplace should concern with instructional design principles. Thus, the results from the finding was successful as it was able to identify the needs of Islamic design Principles in designing multimedia learning and the needs of multimedia learning in preschool education. None the less, these findings will help us to design and develop a multimedia learning for Islamic preschool in future. However, further studies are needed to address on other issue in designing and developing a multimedia learning content.

\subsection{CONCLUSION}

The main goal of the current study was to determine the needs of multimedia learning in preschool children and the need of Islamic design principles in designing the multimedia learning. Consequently, the findings clearly indicate that there are needs of multimedia learning in preschool and the important of integrating Islamic design principles in designing a noble multimedia learning material for Islamic education. However, several limitations to this need study have to be acknowledged; with a small sample size, caution must be applied, as the findings might not be transferable to bigger community. Although the findings should be interpreted with caution, this study has several strengths where all the findings are positive and contain a very high demand factor. None the less, it is recommended that further research be undertaken on the needs of children in rural area for their education.

\section{References}

Abdalla, A., Abu Nimar, M., Nasser, I., Kadayific, A., Kunkle, L., Kilani, el.S., (2003). Improving the Quality of Islamic Education in Developing Countries: Innovative Approaches. Creative Associates International, Inc. Washington D.C.

Ahmad, T.A., \& Said, Z., (2009). Komputer dan Seni Di Era Globalisasi :Peranan Dan Cabaran. Retrieved March, 2016 from http://umkeprints.umk.edu.my/318/.

Ahmad, Z.A., Ahmad, F.R., Saufi, A.H., Dziaudin, S., Nilofar A.H., Siti, R.S., (2006). Study guide for Islamic Studies. Petaling Jaya: Prentice Hall Pearson Malaysia Sdn Bhd.

Ali, W., (2007). Beauty and aesthetic in Islam. Retrieved June, 2017 from www.muslimheritage.com.

Al-Zarnuji, I. (2001) Instruction of the Student: the Method Of Learning (Chicago, IL, The Star latch Press).

Buckhardt, T. (2009). Art of Islam: Language And Meaning. Bloomington, In: World Wisdom Inc.

Clark, R., \& Mayer, R.E. (2008). E-Learning And The Science Of Instruction (2nd ed). San Francisco, CA: Jossey-Bass.

Dani, V., \& Vanishree, P. (2013). Huge Growth Opportunities For Mobile Apps In The Convergence Era. Journal Of Management, 1(1), $61-67$ (ISSN $2347-3940$ (Print), ISSN 2347-3959 (Online), July-December). Doi: 10.1111/j. 1467-9280. 2005.01634. x

Filigree Consulting. (2012). Instructional Technology And Collaborative Learning Best Practices: Global Report And Recommendations. SMART Technologies. Retrieved April 2017 from http://vault.smarttesch.com/assessment/education_whitepapers_web.pdf.

Flaskerud, J. H. (2013). Memory and Memories. Issues in Mental health Nursing, 34 (1), 59-61. Doi:10.3109/01612840.2112.689421

Ginns, P. (2005). Meta-Analysis Of The Modality Effect. Learning and Instruction, 15, 313-331.

Grabar, O. (2006). Islamic Art And Beyond. Burlington, VT: Ashgate Publishing

Greenfield, J. (2013). Students Still Not Taking To E-Textbooks, New Data Show. Digital Book World. Retrieved February, 2016 from http://www.digitalbookworld.com/2013/students-sill-not-taking-to-e-textbooks-new-data-show/.

Harun, A., (2014), Islamic Principles of Graphic Design, Gading Business and Management Journal, 18(2), 19-29.

Hedge, N., and Hayward, L. (2004). Reading roles: University e-Learning Contributing To Life-Long Learning In Networked World. Retrieved January, 2017 from www.nationamaster.com.

J.P. Gee (2003). What Video Games Have to Teach Us About Learning and Literacy. St. Martin's Griffin Publishing, New York

Jones, D. \& Sims, R. (2002). E-Learning Development in Higher Education: Maximising Efficiency - Maintaining Quality. In P. Barker \& S. Rebelsky (Eds.), Proceedings of ED-MEDIA 2002--World Conference on Educational Multimedia, Hypermedia \& Telecommunications, 890-895. Denver, Colorado, USA Association for the Advancement of Computing in Education (AACE). Retrieved July 30, 2018 from https://www.learntechlib.org/primary/p/10277/.

Kalyuga, S., Chandler, P., \& Sweller, J. (2004). When Redundant On-Screen Text In Multimedia Technical Instruction Can Interfere With Learning. Human Factor, 46, $567-581$.

Khan, A., (2003). Islam, Muslims, and America: Understanding the Basis Of Their Conflict. United States: Algora Publishing.

Leahy, W., \& Sweller, J. (2011). Cognitive Load Theory, Modality Of Presentation And The Transient Information Effects. Applied Cognitive Psychology, 25, 943-951. Mayer. R. E (2001), Cognitive Multimedia Learning Theory, Cambridge University.

Mayer. R. E (2003). The Promise Of Multimedia Learning: Using The Same Instructional Design Methods Across Different Media. Learning and Instruction. 13(2), 125-139

Mayer. R.E. and Moreno. R. (2003). Nine Ways To Reduce Cognitive Load In Multimedia Learning. Educational Psychologist, 38, 43-52.

Murray, M. C., \& Perez, J. (2011). E-Textbooks Are Coming: Are We Ready? Issue In Informing Science and Information Technology, 8, 49-60.

National Association for the Education of Young Children (2012). Position Statement: Technology And Young Children. Washington, DC: National Association for the Education of young Children. Retrieved September, 2017 from http://www.naeyc.org/content/technology-and young-children.

O’Neil, H. F., Chuang, S.S, \& Baker, E.L. (2010). Computer-Based Feedback For Computer-Based Collaborative Problem Solving. In D. Ifenthaler et al. (Eds.), Computer-Based Diagnostics and Systematic Analysis of Knowledge, 261-279.

Penuel, W.R., Bates, L., Gallagher, L. P., Pasnik, S., Llorente, C., Townsend, E., et all. (2012). Supplementing Literacy Instruction With A Media-Rich Intervention Results Of A Randomized Controlled Trial. Early Childhood Research Quarterly, 27(2), 115-127.

Presky, M. (2011). Digital Natives, Digital Immigrants. On the Horizon, MCB University Press, 9(5), 1-6

Prince, M. (2004). Does Active Learning Work? A Review of the Research. Journal of Engineering Education, 93, 223-231.

Rahman, T., (2004). The Madrassa and State of Pakistan: Religion, Poverty and Potential for Violence in Pakistan. Retrieved May, 2016 from www.himalmag.com.

Schwarts, G., Howard, M.W., Jing, B., \& kahana, M.J. (2005). Shadows of the Past: Temporal Retrieval Effects In Recognition Memory. Psychological Science, 16 , 898-904.

Talancon, D. R., \& Lieu, D. K. (2012). Media Enhancements For A Pilot Tablet-Based Engineering Design Graphics Textbook. 67th Midyear ASEE Conference Proceedings. Retrieved February, 2016 from http://edge.asee.org/conferences/proceedings/67th\%Midyear\%20proceedings.htm.

Tauhidi, D., (2001). The Tarbiyah Project: Towards a Renewed Vision of Islamic Education. Tarbiyah Project. Crescent Academy International, Canton. Retrieved June, 2017 from http://www.voicesempower.com/wp-content/uploads/2015/11/Tarbiyah-Overview-Dawud-Tauhidi.pdf

Thayer. M., (2011). An Analysis of the Coherence Principle of Multimedia Design. Ed Tech 513. Spring 2011. Project 3.

Umar, W., (2013). The Muslim Book Of Why: What Everyone Should Know About Islam. Bloomington, IN: iUniverse.

Walsh, K. (2010). About Emerging Education and Instructional Technologies and Sharing the Learning Journey. Retrieved March, 2017 from http://www.emergingedtech.comlabout. 
Wang, F., \& Hanafin, M.J. (2005). Design-based research and technology-enhanced learning environments. Educational Technology Research and Development, 53(4), 5-23.York: Palgrave/Macmillan.

Z.L.Lu. \& Sperling. G., (2003). Measuring Sensory Memory: Magnetoencephalography Habituation and Psychophysics. University of Southern California. 